\title{
MOTOR ABILITIES OF CHILDREN OF PREPUBESCENT AGE
}

\section{CAPACIDADES MOTRICES DE LOS NIÑOS DE EDAD PREADOLESCENTE}

\author{
Živan N. Milošević \\ Faculty of Sport and Physical Education, Univeristy of Novi Sad, Student of DAS, Serbia
}

\begin{abstract}
Motor status is an important predictor of physical activity participation among prepubescent aged children. The aim of the present study was to present gender differences in the level of motor abilities among children of prepubescent age. In that regard a reduced "Eurofit" test battery was carried out (Committee of Experts on sports Research, 1988), which consisted of 5 motor tests: hand tap, standing broad jump, running cone drill 10x5m, sit-and-reach and sit-ups for 30 seconds. 420 students of both genders ages 7-9 years participated in this research study. The results of this research indicate that boys have achieved statistically significant better results in the following tests: standing broad jump and running cone drill 10x5m, whilst the girls have achieved better results in sit-and-reach test. No statistically significant differences between genders have been observed in the remaining variables that represent the level of motor ability.
\end{abstract}

Key words: MOTOR ABILITIES / EUROFIT / PREPUBESCENT AGE / SERBIA

\section{INTRODUCTION}

Current research finding indicate that an insufficient and non-satisfactory level physical activity exists among children (Graffiths et al., 2013), with concomitant questionable level of active participation of children in physical education classes (Nettlefold, McKay, Warburton, McGuire, Bredin, \& Naylor, 2011; Simonsmorton, Taylor, Snider, Huang, \& Fulton, 1994), and even among preschoolers the same trend of insufficient levels of physical activity is observed (Bornstein, Beets, Byun,\& McIver, 2011). In addition sedentary behavioral patterns are connected with an increased risk of development of cardiovascular and psychosocial disturbances among children (Tremblay

\section{EXTRACTO}

El estatus motriz representa un importante predictor de la participación de los niños de edad preadolescente en la actividad física. Con este fin se ha aplicado una reducida batería "Eurofit" (Committee of Experts on Sports Research, 1988), que consistió de 5 pruebas motrices: Platte-Tapping, salto horizontal, velocidad 10x5 m, flexión de tronco sentado y acostado. En la investigación participaron los 420 alumnos de edad entre 7-9 años. Los resultados de la investigación indican que los alumnos lograron estadísticamente mucho mejores resultados en las pruebas: salto horizontal y velocidad $10 \times 5 \mathrm{~m}$, mientras que las alumnas han sido mejores en la prueba flexión de tronco sentado. En las demás variables motrices no se han notado las diferencias por sexo en el nivel de capacidades motrices estadísticamente importantes.

Palabras claves: CAPACIDADES MOTRICES / EUROFIT / EDAD PREADOLESCENTE / SERBIA

et al., 2011), as well as with an increased risk of developing obesity (Rowlands, Eston, \& Ingledew, 1999).

Research studies indicate that an adequate level of motor ability in the childhood can be very important for long-term physical fitness and habits of regular physical activity participation in later stages of life (Barnett, Van Beurden, Morgan, Brooks, \& Beard, 2008; Robinson, et al., 2015). Low level of motor abilities is also connected with psychosocial implications (Cummins, Piek, \& Dyck, 2005). Physically active children achieve better results in tests for motor ability evaluation, a better body mass index and a more positive self-perception of their abilities (Sollerhed, 
Apitzsch,, Råstam, \& Ejlertsson, 2007). The feeling of capability to perform a certain activity well, also influences the relationship that children have with physical activity (Ward, Saundres, \& Pate, 2007). A good level of motor ability is positively correlated with academic achievement (Esteban-Cornejo et al., 2014).

Motor status of prepubescent students provides useful information in the process of evaluation of physical fitness, effectiveness of the teaching process, early talent identification, and detection of motor disturbances. Long-term, continuous and uninterrupted monitoring of physical growth and motor ability of students in the scope of physical activity classes at school enables a creation of a database for scientific examination of different aspects in the sphere of motor functioning of children and youth. Non acquaintance with the levels of motor ability of students, carries with it an application, delivery and execution of inadequate training loads in physical education classes which in turn evoke negative consequences on children's health status.

The results of previous research on the sample of children of prepubescent age also shows an existence of gender differences in the levels of motor ability (Obradović, Cvetković, \& Krneta, 2008; Batez, Krsmanović, Dmitrić, \& Pantović, 2011; Gojković, 2010).

Above mentioned facts indicate that the motor literacy of students represents a very important information, because how can we influence the motor status of children, if we haven't previously quantified it, and determined the initial state. Therefore, the main objective of this research is to show the level of motor abilities of students of prepubescent age, to show possible gender differences, and to compare the obtained data with the findings of similar domestic and international research studies. A basic hypothesis was set with the process of documenting the results of former research studies, which states that the differences in motor ability between genders of students of prepubescent age are present.

\section{METHODS}

The data used in this study have been in obtained as part of anthropomotoric testing within the project "Sport to schools - Grow Healthily" which was carried out on the territory of Sabac municipality in the 2015-2016 school year. Direct measurements of anthropomotorical abilities have been carried out by trained and experienced physical education teachers which are all members of "Sport-diagnostic center Sabac". Parents of the participants were informed about the entire testing procedure, and they provided and informed consent for the participation of their children in the testing procedures. The total of 420 students of both genders, ages 7-10 executed the anthropometric tests. The order of test execution was the following: 1) body height; 2) bodyweight; 3 ) hand tap; 4) sit-and-reach; 5) standing broad jump; sit-ups for 30seconds; 7) running cone-drill 10x5m.

Sit-and-reach - as a measure of flexibility estimation of lumbar spine and the hamstring musculature. Equipment used for this test was a wooden box with the following dimensions $45 \times 35 \times 32 \mathrm{~cm}$ with a sliding ruler which was placed on the board scale which a subject pushes with his or her hands. The subjects sits in front of the box, with legs extended and positions his or feet on the front side of the box. The examiner should kneel next to the subject and press the subjects knees into the floor, thus disabling any knee flexion to occur during test execution. The motor test of the subject is to lean forward as far as possible without flexing the knee joint, with hands extended in front of his body and to evenly push the sliding ruler. The furthest position which a subject has obtained with his fingertips without an arm swing is recorded as a result. Each subject has 2 trials, and the best result measured in centimeters is recorded. For easier statistical analysis on the obtained results $20 \mathrm{~cm}$ value was added.

Standing broad jump - as a measure of muscle strength. Equipment used for this test were a measuring tape, flat, non-slippery surface with a marked jumping area. The motor task given to the subject was to jump as far as possible with both feet concomitantly. The farthest point of contact of the heel with the surface, that is the second trace which is the most proximal to the starting jumping position is taken and recorded as a results, expressed in centimeters.

Sit-ups for 30 seconds - as a measure of muscle strength endurance. Equipment used in this test were a stopwatch and a mat. The beginning position of a subject is lying supine with palms on the back of the head, hands crossed, and with legs flexed at 90 degrees in the knee joint, which are fixated by the tester. From the starting position the subject should perform a maximal number of trunk flexions (a.k.a sit-ups) within 30 seconds, so as to touch the elbows with his knees during each repetition. 
Running cone drill $10 \times 5 \mathrm{~m}$ - as a measure of agility. Equipment used in this test were cones, a marked running track with a clean non-slippery surface. The track is marked by placing two parallel lines $1.2 \mathrm{~m}$ in length $5 \mathrm{~m}$ apart from each other. The subjects positions him or herself in a starting position behind the starting line, and on the onset of an audible signal begins to run as fast as possible on a marked track all the way to the other end of the track, which he or she must cross with both feet, and this running cone drill cycle is executed 5 times. After the end of the fifth cycle, time is stopped, and the results is recorded to 0.1 seconds of accuracy.

Hand tap - as a measure of alternate movements. Equipment used for this test were a height-adjustable desk, two rubber disks both $20 \mathrm{~cm}$ in diameter attached horizontally to the upper surface of the table, separated by $80 \mathrm{~cm}(60 \mathrm{~cm}$ between the edges of the circles) - a rectangle shaped plate $10 \times 20 \mathrm{~cm}$, positioned on an even distance between the disks, and a stopwatch. The motor task for the subjects was to alternately touch the two disks with their dominant arm as quickly as possible. Subject was seated on a chair, feet shoulder width a part, free resting arm was positioned on a rectangle shaped plate in the center, and the dominant working hand was placed on the opposite disk. Moving his or her hand from one disk to the other over the resting hand which was resting on the rectangle shaped plate for the entire test. After performing 25 cycles ( 1 cycle represents the touch of the opposite disk and returning to the starting disk) as quickly as possible, time was stopped, and the results was recorded to the closest 0.1 seconds.

Sample of participants was divided into three subgroups based on the chronological age, 7, 8 and 9 year old students, as well as based on gender into two subgroups, boys and girls. Basic indicators of descriptive statistics have been presented for all motor tests, whilst for the testing of deviation from normal distribution a Kolmogorov-Smirnov test was used. The differences in the level of motor abilities of participants of different genders were analyzed with the application of Mann-Whitney test. The statistical significance level was set at $\mathrm{p} \leq .05$. Statistycal analysis was carried out via the application of SPSS software package (v19.0, SPSS Inc., Chicago, IL, USA).

\section{RESULTS}

Basic characteristics of the formed subsamples based on the age criteria and gender are shown in Table 1.

Table 1. Basic characteristics of the sample.

\begin{tabular}{llll}
\hline Age & Boys $(\mathbf{n}=\mathbf{1 7 4})$ & Girls $(\mathbf{n}=\mathbf{2 1 7})$ & Total $(\mathbf{n}=\mathbf{3 9 1})$ \\
\hline $\mathbf{7}$ years & $78(44,8 \%)$ & $86(39,6 \%)$ & $164(23,3 \%)$ \\
$\mathbf{8}$ years & $54(31,0 \%)$ & $82(37,8 \%)$ & $136(34,8 \%)$ \\
9 years & $42(24,1 \%)$ & $49(22,6 \%)$ & $91(41,9 \%)$ \\
\hline
\end{tabular}

Basic anthropometric characteristics of the sample: body height, body weight and body mass index of both genders are shown in Table 2.

Table 2. Anthropometric characteristics based on gender and age of students.

\begin{tabular}{|c|c|c|c|c|c|c|c|c|c|c|c|c|}
\hline \multirow{3}{*}{ Age } & \multicolumn{6}{|c|}{ Boys } & \multicolumn{6}{|c|}{ Girl } \\
\hline & \multicolumn{2}{|c|}{ Height $(\mathrm{cm})$} & \multicolumn{2}{|c|}{ Weight (кg) } & \multicolumn{2}{|c|}{$\begin{array}{c}\text { Body mass } \\
\text { index }\left(\mathbf{k g m}^{2}\right)\end{array}$} & \multicolumn{2}{|c|}{ Height $(\mathrm{cm})$} & \multicolumn{2}{|c|}{ Weight (кg) } & \multicolumn{2}{|c|}{$\begin{array}{l}\text { Body mass index } \\
\qquad\left(\mathrm{kgm}^{2}\right)\end{array}$} \\
\hline & $\mathbf{M}$ & SD & $\mathbf{M}$ & SD & $\mathbf{M}$ & SD & $\mathbf{M}$ & SD & M & SD & $\mathbf{M}$ & SD \\
\hline 7 years & 129.63 & 5.71 & 28.76 & 6.30 & 16.98 & 2.77 & 127.97 & 6.00 & 27.70 & 6.25 & 16.78 & 2.89 \\
\hline 8 years & 134.11 & 6.62 & 31.04 & 7.69 & 17.08 & 3.08 & 133.26 & 6.51 & 29.78 & 8.10 & 16.60 & 3.35 \\
\hline 9 years & 141.64 & 6.12 & 34.24 & 7.53 & 16.93 & 2.80 & 141.20 & 6.90 & 35.49 & 7.84 & 17.68 & 3.09 \\
\hline
\end{tabular}


Table 3. Level of motor ability of prepubescent children according to gender and age (values of descriptive statistics, Kolmogorov-Smirnov test, and Mann-Whitney test).

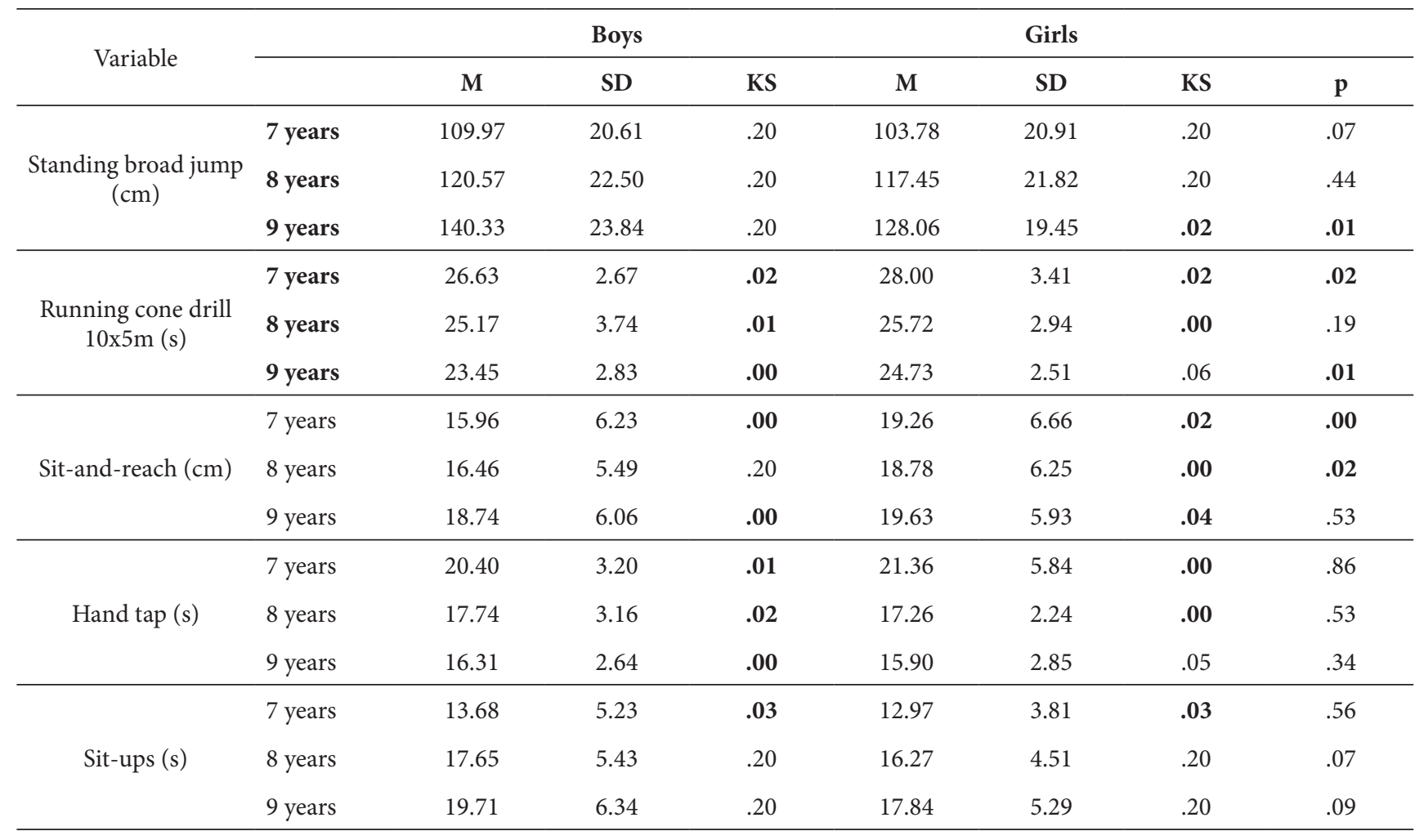

Results of basic descriptive indicators for five motor tests, as well as Kolmogorov-Smirnov test of normal distribution are presented in Table 3. Due to the facts that among most of the variables within both genders a statistical deviation from normal distribution is present, a non-parametric statistical test was used for testing gender differences based on motor abilities, that is the Mann-Whitney test. By observing the results from Table 3. we can see statistically significant differences in variables standing broad jump in favor of 9 year-old boys $(\mathrm{p}=.01)$. Both 7 year-old $(\mathrm{p}=.02)$ and 9 year-old boys $(\mathrm{p}=.01)$ have achieved statistically better results in the running cone drill $10 \times 5 \mathrm{~m}$. Girls have achieved better results in the sitand-reach test, in two age categories, 7 year-old $(\mathrm{p}=.00)$ and 8 year-old $(\mathrm{p}=.02)$.

\section{DISCUSSION}

The aim of the present study was to show the level of motor abilities of prepubescent students, ages 7-9. As a measuring device for estimation of the level of motor abilities a reduced EUROFIT battery of motor tests was used which consisted of 5 tests: hand tap, sit-and-reach, sit-ups for 30 seconds, running cone drill 10x5m and standing broad jump. The sample of participants was divided into three subsamples based on the age criteria: subjects of 7, 8 and 9 years of age.

Boys, as in comparative study (Milanese, Bortolami, Bertucco, Verlato, \& Zancanaro, 2010, Stupar, 2012, Thomas, \& Palma, 2018) have achieved better results in the standing broad jump test at the age of 9. Boys, in this opservation, as is in comparative one (Lazarević, Milosavljević, Lazarević, Marković, \& Savić, 2018), have achieved better results in the running cone drill test $10 \times 5 \mathrm{~m}$ in the age group of first and third grade of elementary school

By analysing gender differences in the test „standing broad jump" and "running cone drill 10x5m" environmental factors such as previous practice, maturation, family influence should be taken into consideration. It may be assumed that the gender differences are influenced by the different interests in physical activity type, as well as differential social expectations (Nikolić, Mraković, \& Horvat, 2013, according to: Malina, \& Bouchard, 1991). In addition, stereotypical gender roles and sport distribution to those which have a high demand of physical strength and 
aggression and those sports that mostly interest boys, as opposed to those sports such as gymnastics which engage more feminine characteristics, such as graciousness and agility and which pose such stereotypical roles on girls should be taken into consideration (Eccles, \& Harold, 1991).

Girls, as is in comparative study (Raudsepp \& Pääsuke, 1995), achieved better results in the sit-andreach test in the age group of 8 years old girls Better results of girls in the flexibility tests are in congruence with the resuls of previous research (Lazarevic, et al., 2018, Krska, Sedlacek, Hubinak, Kostial, \& Teplicancova, 2017). Girls, as is incomparative study (Čillík et. al, 2014; Čillík, Kollár, Kremnický, Pivovarnicek, \& Mandzáková, 2015; Krska et al., 2017) outperformed the boys in the sit-and-reach test in the 7 year-old age group. Greater flexibility and mobility of girls compared to boys can be explained by anatomical differences and genetic potentials (Jevtić, Radojević, Juhas, Ropret, 2011).

\section{REFERENCES}

1. Barnett, L. M., Van Beurden, E., Morgan, P. J., Brooks, L. O., \& Beard, J. R. (2008). Does childhood motor skill proficiency predict adolescent fitness?. Medicine \& Science in Sports \& Exercise, 40(12), 2137-2144.

2. Batez, M., Krsmanović, B., \& Dmitrić, G. i Pantović, M.(2011). Razlike u nivou motoričkih sposobnosti učenika i učenica mlađeg školskog doba [ Differences in the level of motor skills of young students. In Serbian]. Sport i Zdravlje, 4(2), 32-37.

3. Bornstein, D. B., Beets, M. W., Byun, W., \& McIver, K. (2011). Accelerometer-derived physical activity levels of preschoolers: a meta-analysis. Journal of Science and Medicine in Sport, 14(6), 504-511.

4. Cillík, I., Kollár, R., Kremnický, J., Pivovarnicek, P., \& Mandzáková, M. (2015). The level of general physical performance and physical development of 7 and 10-year-old boys and girls. Journal of $\mathrm{Hu}$ man Sport and Exercise, 10(1), 259-268.

5. Čillík, I., Kollár, R., Kremnický, J., Pivovarniček, P., Kováčiková, M., Ďurják, O., Švachova, S. \& Murínová, A. (2014). Nivo opštih fizičkih performansi i fizičkog razvoja učenika uzrasta
Based on the results of this and previous research studies, it can be concluded that systemic monitoring of physical growth and maturation of prepubescent students is mandatory. The results of motor testing contribute a multitude of benefits to students, they gear them towards development and perfection of their own predispositions, provide them useful information about their own level of motor abilities. Continuous monitoring of motor abilities of students in the context of physical education classes has a task to provide every students with information of their own level of motor abilities, so that on the basis of obtained results he or she can get certain recommendations and advices on how to improve his or her motor potential, as well as to education students during testing procedure and help them to understand the significance and the role of physical activity and motor abilities for their health.

od 7 godina u Banskoj Bistrici (Banská Bystrica) [Level of general physical performance and physical development of students aged 7 years in Banska Bistrica. In Serbian]. Sportske nauke i zdravlje, 7(1).

6. Committee of Experts on sports Research. (1988). EUROFIT: European Test of Physical Fitness. Strasbourg, France: Council of Europe.

7. Cummins, A., Piek, J. P., \& Dyck, M. J. (2005). Motor coordination, empathy, and social behaviour in school-aged children. Developmental medicine and child neurology, 47(7), 437-442.

8. Eccles, J. S., \& Harold, R. D. (1991). Gender differences in sport involvement: Applying the Eccles' expectancy-value model. Journal of applied sport psychology, 3(1), 7-35.

9. Esteban-Cornejo, I., Tejero-González, C. M., Martinez-Gomez, D., Del-Campo, J., GonzálezGalo, A., Padilla-Moledo, C., Salis J., \& Veiga, O.(2014). Independent and combined influence of the components of physical fitness on academic performance in youth. The journal of pediatrics, 165(2), 306-312.

10. Gojković, G. (2010). Razlike motoričkih sposobnosti u odnosu na pol učenika.[ Differences 
in motor skills in relation to students' gender. In Serbian] Sport Mont, 8 (23-24), 423-428.

11. Griffiths, L. J., Cortina-Borja, M., Sera, F., Pouliou, T., Geraci, M., Rich, C., Cole, T., Law, K., Joshi, H.,Ness, A.,Dezateux, C., \& Jebb, S. A. (2013). How active are our children? Findings from the Millennium Cohort Study. BMJ open, 3(8), e002893

12. Jevtić, B., Radojević, J., Juhas, I., \& Ropret, R. (2011). Dečiji sport od prakse do akademske oblas$t i$ [ Children's sport from practice to academic discipline. In Serbian]. Beograd: Fakultet sporta i fizičkog vaspitanja.

13. Krska, P., Sedlacek, J., Hubinak, A., Kostial, J., \& Teplicancova, M. (2017). Somatic parameters and general physical fitness level of school children (7-10 years) in town Ruzomberok in Slovakia. Gymnasium, 15(2).

14. Lazarević, P., Milosavljević, S., Lazarević, S., Marković, V., \& Savić, A. (2018). Different levels of motor abilities in boys and girls aged 10 and 9 . Facta Universitatis, Series: Physical Education and Sport, 16(1), 189-199.

15. Malina, M.R., \& Bouchard, C. (1991). Growth, maturation and physical activity. Human Kinetics Books: Champaign, 187-204.

16. Milanese, C., Bortolami, O., Bertucco, M., Verlato, G., \& Zancanaro, C. (2010). Anthropometry and motor fitness in children aged 6-12 years. Journal of Human Sport and Exercise, 5(2), 265-279.

17. Nettlefold, L., McKay, H. A., Warburton, D. E. R., McGuire, K. A., Bredin, S. S. D., \& Naylor, P. J. (2011). The challenge of low physical activity during the school day: at recess, lunch and in physical education. British Journal of Sports Medicine, 45(10), 813-819.

18. Nikolić, I., Mraković, S., \& Horvat, V. (2013). Standing long jump performance quality: Age and gender differences. Croatian Journal of Education, 15(1), 173-183.

19. Obradovic, J., Cvetkovic, M., \& Krneta, Z. (2008). Differences of motor abilities of 7-11 years old children according to geneder. Sport Mont, VI(1516-17), 527-533

20. Raudsepp, L., \& Pääsuke, M. (1995). Gender differences in fundamental movement patterns, motor performances, and strength measurements of prepubertal children. Pediatric Exercise Science, 7(3), 294-304.

21. Robinson, L. E., Stodden, D. F., Barnett, L. M., Lopes, V. P., Logan, S. W., Rodrigues, L. P., \& D'Hondt, E. (2015). Motor competence and its effect on positive developmental trajectories of health. Sports medicine, 45(9), 1273-1284.

22. Rowlands, A. V., Eston, R. G., \& Ingledew, D. K. (1999). Relationship between activity levels, aerobic fitness, and body fat in 8-to 10-yr-old children. Journal of Applied Physiology, 86(4), 1428-1435.

23. Simonsmorton, B. G., Taylor, W. C., Snider, S. A., Huang, I. W., \& Fulton, J. E. (1994). Observed levels of elementary and middle school children's physical activity during physical education classes. Preventive Medicine, 23(4), 437-441.

24. Sollerhed, A. C., Apitzsch, E., Råstam, L., \& Ejlertsson, G. (2007). Factors associated with young children's self-perceived physical competence and self-reported physical activity. Health Education Research, 23(1), 125-136.

25. Stupar, D. (2012). Differences in anthropometric characteristics and motor abilities between boys and girls age 7: Meta-analysis. TIMS. Acta, 6(2), 57-64.

26. Thomas, E., \& Palma, A. (2018). Physical Fitness Evaluation of School Children in Southern Italy: A Cross Sectional Evaluation. Journal of Functional Morphology and Kinesiology, 3(1), 14.

27. Tremblay, M. S., LeBlanc, A. G., Kho, M. E., Saunders, T. J., Larouche, R., Colley, R. C., Goldfield, G., \& Gorber, S. C. (2011). Systematic review of sedentary behaviour and health indicators in school-aged children and youth. International journal of behavioral nutrition and physical activity, 8(1), 98. 


\title{
МОТОРИЧКЕ СПОСОБНОСТИ ДЕЦЕ ПРЕТПУБЕРТЕТСКОГ УЗРАСТА
}

\author{
Живан Н. Милошевић \\ Факултет спорта и физичког васпитања, Универзитет у Новом Саду, студент ДАС, Србија
}

\begin{abstract}
Сажетак
Моторички статус представља битан предиктор учешћа деце претпубертетског узраста у физичкој активности. Спроведено истраживање имало је за циљ да прикаже полне разлике у нивоу моторичких способности деце претпубертетског узраста. У ту сврху примењена је редукована „Еурофит“ батерија (Committee of Experts on sports Research, 1988), која се састојала из 5 моторичких тестова: тапинг руком, скок удаљ из места, чунасто трчање $10 x 5 \mathrm{M}$, претклон у седу и лежање-сед. У истраживању је учествовало 420 ученика, оба пола, узраста 7-9 година. Резултати истраживања указују да су ученици постигли статистички значајно боље резултате у тестовима: скок удаљ из места и чунасто трчање 10х5м, док су ученице биле боље у тесту претклон у седу. У осталим моторичким варијаблама нису уочене статистички значајне полне разлике у нивоу моторичких способности.
\end{abstract}

Кључне речи: МОТОРИЧКЕ СПОСОБНОСТИ / ЕУРОФИТ/ ПРЕТПУБЕРТЕТСКИ УЗРАСТ / СРБИЈА

\section{УВОД}

Истраживања указују на незадовољавајући ниво физичке активности деце (Graffiths et al., 2013), упитан је и ниво ангажованости деце на настави физичког васпитања (Nettlefold, McKay, Warburton, McGuire, Bredin, \& Naylor, 2011; Simonsmorton, Taylor, Snider, Huang, \& Fulton, 1994), чак се и код деце предшколског узраста уочава исти тренд недовољног нивоа физичке активности (Bornstein, Beets, Byun,\& McIver, 2011). Такође седентарни обрасци понашања повезани су са повећаним ризиком појаве кардиоваскуларних и психосоцијалних поремећаја код деце (Tremblay et al., 2011), и повећаним ризиком од појаве гојазности (Rowlands, Eston, \& Ingledew, 1999).

Како теорија, тако и пракса указује да адекватан ниво моторичких способности у детињству може бити веома важан за целоживотну физичку активност и навике вежбања у каснијим периодима живота (Barnett, Van Beurden, Morgan, Brooks, \& Beard, 2008; Robinson, et al., 2015). Низак ниво моторичких способности повезан је и са психосоцијалним импликацијама (Cummins, Piek, \& Dyck, 2005). Физички активна деца имају боље резултате у тестовима за процену моторичких способности, повољнији индекс телесне масе и позитивнију самоперцепцију својих способности (Sollerhed, Apitzsch, Råstam, \& Ejlertsson, 2007). На однос деце према физичкој активности, утицај има и то, да ли се она осећају способном за дату активност (Ward, Saundres, \& Pate, 2007). Добар ниво моторичких способности позитивно се односи и на академско постигнуће (EstebanCornejo et al., 2014).

Моторички статус ученика претпубертетског узраста пружа корисне информације у процесу евалуације физичке ангажованости, ефективности наставног процеса, ране идентификације талената и детекције моторичких поремећаја. Континуирано праћење физичког развоја и моторичких способности ученика у оквиру наставе физичког васпитања омогућава стварање базе података за континуирано проучавања различитих аспеката у простору моторичког функционисања деце и младих. Непознавање нивоа моторичких способности ученика, носи са собом могућност примену неадекватног оптерећења, што може имати негативне последице на здравствени статус ученика. 
Резултати претходних истраживања на узорку деце млађег школског узраста такође указују на постојање полних разлика у простору моторичких способности (Obradović, Cvetković, \& Krneta, 2008; Batez, Krsmanović, Dmitrić, \& Pantović, 2011; Gojković, 2010).

Наведено указује да познавање нивоа моторичких способности ученика представља веома битан податак, јер како се може утицати на моторички простор деце, ако се претходно није квантификовало, и утврдило иницијално стање. Стога је циљ овог истраживања да прикаже ниво моторичких способности ученика претпубертетског узраста, укаже на евентуалне полне разлике, као и да добијене резултате упореди са сличним истраживањима у земљи и иностранству. Документујући резултате досадашњих истраживања, постављена је основна хипотеза да постоје полне разлике у нивоу моторичких способности ученика претпубертетског узраста.

\section{МЕТОД РАДА}

Подаци коришћени у истраживању, прикупљени су у оквиру антропомоторичких мерења у Пројекту „Спорт у школе - Расти здраво“ реализованог на територији града Шапца у школској 2015/2016. години. Непосредно мерење антропомоторичких способности спровели су обучени мериоци, чланови „Спортско-дијагностичког центра Шабац“, дипломирани професори физичког васпитања и спорта. Родитељи испитаника били су упознати са целокупном процедуром мерења, и дали су писану сагласност за учешће њихове деце у овој студији. Кроз антропомоторичка тестирања прошло је укупно 420 испитаника, оба пола, старости од 7-10 година.

\section{Поступак мерења}

Редослед мерења је обухватио следеће мере: 1) телесна висина ; 2) телесна маса ; 3) тапинг руком; 4) претклон у седу ; 5) скок удаљ из места; 6) прегиби трупом за 30 секунди; 7) чунасто трчање $10 \times 5 \mathrm{M}$.
Претклон у седу - као мера за процену гипкости доњег дела кичменог стуба и задње ложе бута. Од реквизита за реализацију овог теста користи се дрвени сандук димензија 45×35×32 цм са клизним лењиром који се налази на скали плоче који испитаник потискује рукама. Испитаник заузима седећи положај испред сандука, опруженим ногама поставља стопала на предњу страну сандука. Испитивач треба да заузме клечећи положај поред испитаника и да му притиском на колена онемогући да погрчи ноге приликом извођења теста. Задатак испитаника је да са испруженим рукама испред себе, не грчећи ноге, нагне напред што је могуће више и равномерно рукама гура клизни лењир. Као резултат бележи се најдаља позиција коју је испитаник досегао врховима прстију без замаха. Сваки испитаник има право на два покушаја, и бележи се бољи резултат изражен у сантиметрима. Ради лакше статистичке обраде на добијене резултате додата је вредност од 20 цм.

Скок удаљ - као мера за процену мишићне снаге. Од реквизита за реализацију овог теста потребни су мерна трака, равна, неклизајућа подлога, и површина са обележеним скакалиштем. Задатак испитаника је да суножним одскоком скочи што даље. Као резултат изражен у сантиметрима,бележи се тачка додира пета са површином, односно други траг који је најближи линији одскока.

Лежање-сед за 30 секунди - као мера издржљивости у мишићној снази. Од реквизита за реализацију овог теста потребни су штоперица, и струњача. Почетни положај у којем се налази испитаник је лежећи на леђима са рукама преплетеним на потиљку и ногама погрченим у коленима под углом од 90 степени, фиксираним од стране мериоца. Из почетног, лежећег положаја, испитаник треба да направи максималан број прегибања напред у року од 30 секунди, тако да приликом сваког понављања лактовима додирне колена.

Чунасто трчање 10х5м - као мера агилности. Од реквизита за реализацију овог теста потребни су чуњеви, обележена стаза за трчање на чистом, неклизајућем поду. Стаза се обележава тако што се на међусобном растојању од 5 метара на поду обележе две паралелне линије дужине 1,2м. Испитаник заузима почетну позицију иза стартне линије, и на звучни сигнал почиње да трчи најбрже могуће по означеној стази до линије 
на другом крају стазе коју мора да пређе са оба стопала, и тај циклус чунастог трчања понавља 5 пута. Након завршетка петог циклуса, време се зауставља, и бележи остварени резултат у десетинкама секунде.

Тапинг руком - као мера брзине алтернативних покрета. Од реквизита за реализацију овог теста потребни су сто подесив по висини, два гумена диска пречника 20 цм причвршћена хоризонтално на сто, са размаком између центара 80 цм (између ивица 60 цм) - четвороугаона плоча димензија 10х20 цм, постављена на једнакој удаљености између дискова, штоперица. Задатак испитаника је да брзо наизменично додирује две плоче доминантном руком. Испитаник седне за сто, мало рашири стопала, постави шаку слободне руке на четвороугаону плочу у центру, a шаку изабране руке постави на супротан диск. Пребацује изабрану шаку са диска на диск што је брже могуће преко руке која је све време на четвороуглу у средини. Након што изврши 25 циклуса (један циклус представља додир супротног диска и враћање на полазни диск) што је брже могуће, време се зауставља, и бележи остварени резултат у десетинкама секунде.

\section{Узорак испитаника}

Узорак испитаника био је подељен по два критеријума: критеријум хронолошке старости (ученике старости седам, осам и девет година), критеријум полне припадности (два субузорка, мушки и женски).

\section{Обрада података}

За све моторичке тестове приказани су основни показатељи дескриптивне статистике, док је за тестирање одступања од нормалности дистрибуције примењен Колмогоров - Смирнов тест. Разлике у нивоу моторичких способности испитаника различитог пола, анализиране су применом Ман - Витнеј теста. Гранични ниво значајности дефинисан је на нивоу $\mathrm{p} \leq .05$. Статистичка обрада података спроведена је применом статистичког програма СПСС (v19.0, SPSS Inc., Chicago, IL, USA).

\section{РЕЗУЛТАТИ}

У Табели 1 приказане су основне карактеристике три формирана субузорка по старосном критеријуму и полу.

Табела 1 Основне карактеристике узорка

\begin{tabular}{llll}
\hline Старост & Дечаци $(\mathbf{H = 1 7 4 )}$ & Девојчице $(\mathbf{H = 2 1 7 )}$ & Укупно $(\mathbf{H = 3 9 1 )}$ \\
\hline 7 година & $78(44,8 \%)$ & $86(39,6 \%)$ & $164(23,3 \%)$ \\
8 година & $54(31,0 \%)$ & $82(37,8 \%)$ & $136(34,8 \%)$ \\
9 година & $42(24,1 \%)$ & $49(22,6 \%)$ & $91(41,9 \%)$ \\
\hline
\end{tabular}

У Табели 2 приказана су основна антропометријска обележја узрока: телесна висина, телесна тежина, и на основу њих изведен индекс телесне масе испитаника оба пола.

Табела 2 Антропометријска обележја према полу и старости ученика

\begin{tabular}{|c|c|c|c|c|c|c|c|c|c|c|c|c|}
\hline \multirow[t]{3}{*}{ Старост } & \multicolumn{6}{|c|}{ Дечаци } & \multicolumn{6}{|c|}{ Девојчице } \\
\hline & \multicolumn{2}{|c|}{ Висина(цм) } & \multicolumn{2}{|c|}{ Тежина (кг) } & \multicolumn{2}{|c|}{$\begin{array}{l}\text { Индекс телесне } \\
\text { масе }\left(\text { (км }^{2}\right)\end{array}$} & \multicolumn{2}{|c|}{ Висина (цм) } & \multicolumn{2}{|c|}{ Тежина (кг) } & \multicolumn{2}{|c|}{$\begin{array}{l}\text { Индекс телесне } \\
\text { масе }\left(\text { кгм²) }^{2}\right)\end{array}$} \\
\hline & $\mathbf{M}$ & SD & $\mathbf{M}$ & SD & $\mathbf{M}$ & SD & M & SD & $\mathbf{M}$ & SD & $\mathbf{M}$ & SD \\
\hline 7 година & 129.63 & 5.71 & 28.76 & 6.30 & 16.98 & 2.77 & 127.97 & 6.00 & 27.70 & 6.25 & 16.78 & 2.89 \\
\hline 8 година & 134.11 & 6.62 & 31.04 & 7.69 & 17.08 & 3.08 & 133.26 & 6.51 & 29.78 & 8.10 & 16.60 & 3.35 \\
\hline 9 година & 141.64 & 6.12 & 34.24 & 7.53 & 16.93 & 2.80 & 141.20 & 6.90 & 35.49 & 7.84 & 17.68 & 3.09 \\
\hline
\end{tabular}


Милошевић Ж., Моторичке способности деце..., ФИЗИЧКА КУЛТУРА 2019; 73 (2): 271-276

Табела 3 Ниво моторичких способности деце претпубертетског узраста према полу и старости ученика (вредности дескриптивне статистике, Колмогоров - Смирнов тест, и Ман - Витнеј тест)

\begin{tabular}{|c|c|c|c|c|c|c|c|c|}
\hline \multirow[t]{2}{*}{ Варијабла } & \multicolumn{3}{|c|}{ Дечаци } & \multicolumn{3}{|c|}{ Девојчице } & \multirow[b]{2}{*}{ кС } & \multirow[b]{2}{*}{$\mathbf{p}$} \\
\hline & & M & СД & КС & M & СД & & \\
\hline \multirow{3}{*}{ Скок удаљ (цм) } & 7 година & 109.97 & 20.61 & .20 & 103.78 & 20.91 & .20 & .07 \\
\hline & 8 година & 120.57 & 22.50 & .20 & 117.45 & 21.82 & .20 & .44 \\
\hline & 9 година & 140.33 & 23.84 & .20 & 128.06 & 19.45 & .02 & .01 \\
\hline \multirow{3}{*}{$\begin{array}{c}\text { Чунасто трчање } \\
10 \times 5 \mathrm{M}(\mathrm{c})\end{array}$} & 7 година & 26.63 & 2.67 & .02 & 28.00 & 3.41 & .02 & .02 \\
\hline & 8 година & 25.17 & 3.74 & .01 & 25.72 & 2.94 & .00 & .19 \\
\hline & 9 година & 23.45 & 2.83 & .00 & 24.73 & 2.51 & .06 & .01 \\
\hline \multirow{3}{*}{$\begin{array}{c}\text { Претклон у седу } \\
\text { (цм) }\end{array}$} & 7 година & 15.96 & 6.23 & .00 & 19.26 & 6.66 & .02 & .00 \\
\hline & 8 година & 16.46 & 5.49 & .20 & 18.78 & 6.25 & .00 & .02 \\
\hline & 9 година & 18.74 & 6.06 & .00 & 19.63 & 5.93 & .04 & .53 \\
\hline \multirow{3}{*}{ Тапинг руком (c) } & 7 година & 20.40 & 3.20 & .01 & 21.36 & 5.84 & .00 & .86 \\
\hline & 8 година & 17.74 & 3.16 & .02 & 17.26 & 2.24 & .00 & .53 \\
\hline & 9 година & 16.31 & 2.64 & .00 & 15.90 & 2.85 & .05 & .34 \\
\hline \multirow{3}{*}{ Лежање-сед(c) } & 7 година & 13.68 & 5.23 & .03 & 12.97 & 3.81 & .03 & .56 \\
\hline & 8 година & 17.65 & 5.43 & .20 & 16.27 & 4.51 & .20 & .07 \\
\hline & 9 година & 19.71 & 6.34 & .20 & 17.84 & 5.29 & .20 & .09 \\
\hline
\end{tabular}

У Табели 3 дати су резултати основних дескриптивних показатеља код пет примењених моторичких тестова, као и Колмогоров - Смирнов тест нормалности дистрибуције. С обзиром да у већини варијабли код испитаника оба пола постоји статистичко одступање од нормалности дистрибуције, за тестирање полних разлика у нивоу моторичких способности коришћена је непараметријска статистика, односно Ман - Витнеј тест.

Посматрајући резултате у Табели 3 уочавају се статистички значајне разлике у варијаблама скок удаљ у корист дечака старости 9 година $(\mathrm{p}=.01)$; у тесту чунасто трчање $10 \times 5 \mathrm{~m}$ статистички боље резултате остварили су дечаци узраста 7 година $(\mathrm{p}=.02)$ и дечаци узраста 9 година $(\mathrm{p}=.01)$. Девојчице су боље резултате оствариле у тесту претклон у седу, у две узрасне категорије, од 7 година $(\mathrm{p}=.00)$ и 8 година $(\mathrm{p}=.02)$.

\section{ДИСКУСИЈА}

Спроведено истраживање имало је за циљ да прикаже ниво моторичких способности ученика претпубертетског узраста, старости 7-9 година. Као мерни инструмент за процену нивоа моторичких способности коришћена је редукована ЕУРОФИТ батерија моторичких тестова која се састојала од 5 тестова: тапинг руком, претклон у седу, лежање - сед за 30 секунди, чунасто трчање $10 x 5 \mathrm{M}$, и скок удаљ. Узорак испитаника је према старосном критеријуму био подељен на три субузорка: испитанике старости 7, 8 и 9 година.

Дечаци у овом посматрању, као и у компаративним другим студијама (Milanese, Bortolami, Bertucco, Verlato, \& Zancanaro, 2010, Stupar, 2012, Thomas, \& Palma, 2018). су остварили боље резултате у тесту скок удаљ у узрасту 9 година. Дечаци су постигли боље резултате у тесту 10x5 
метара у узрасту трећег и првог разреда. Исто је утврђено у другим националним стидијама (Lazarević, Milosavljević, Lazarević, Marković, \& Savić, 2018). Анализирајући полне разлике у тестовима скок удаљ и трчање $10 x 5$ метара треба узети у разматрање и срединске факторе, попут претходног моторичког и спортског искуства испитаника, њихово сазревање, утицаја породице и слично. Може се претпоставити да су полне разлике условљене различитим интересовањима за физичку активност, као и различитим друштвеним очекивањима (Nikolić, Mraković, \& Horvat, 2013, prema: Malina, \& Bouchard, 1991). Такође треба узети у обзир стереотипне родне улоге и поделе спортова на оне који захтевају физичку снагу и агресивност и који више ангажују дечаке, наспрам спортова попут гимнастике, који укључује више женствених карактеристика, као што су грациозност и агилност, и које намећу такву стереотипну улогу девојчицама (Eccles, \& Harold, 1991).

Девојчице у овом посматрању, као и у компаративним другим студијама (Raudsepp \& Pääsuke, 1995), су постигле боље резултате у тесту претклон у седу у узрасту 8 година Бољи резултати ученица у тестовима гипкости сагласни су и са резултатима претходних истраживања (Lazarevic, et al., 2018, Krska, Sedlacek, Hubinak, Kostial, \& Teplicancova, 2017). Девојчице су се показале као

\section{ЛИТЕРАТУРА}

1. Barnett, L. M., Van Beurden, E., Morgan, P. J., Brooks, L. O., \& Beard, J. R. (2008). Does childhood motor skill proficiency predict adolescent fitness?. Medicine \& Science in Sports \& Exercise, 40(12), 2137-2144.

2. Batez, M., Krsmanović, B., \& Dmitrić, G. i Pantović, M.(2011). Razlike u nivou motoričkih sposobnosti učenika i učenica mlađeg školskog doba. Sport i Zdravlje, 4(2), 32-37.

3. Bornstein, D. B., Beets, M. W., Byun, W., \& McIver, K. (2011). Accelerometer-derived physical activity levels of preschoolers: a meta-analysis. Journal of Science and Medicine in Sport, 14(6), 504-511.

4. Cillík, I., Kollár, R., Kremnický, J., Pivovarnicek, P., \& Mandzáková, M. (2015). The level of general боље, као и у компартивним студијама (Čillík et. al, 2014; Čillík, Kollár, Kremnický, Pivovarnicek, \& Mandzáková, 2015; Krska et al., 2017) cy ce показале као боље у тесту претклон у седу од дечака у узрасту од 7 година Већа покретљивост ученица спрам ученика може се објаснити анатомским разликама и различитим генетским потенцијалима (Jevtić, Radojević, Juhas, Ropret, 2011).

Узимајући у обзир резултате овог и претходних истраживања, долази се до закључка да је систематско праћење физичког раста и развоја ученика претпубертетског узраста неопходно. Резултати моторичких тестирања доносе многобројне бенефите ученицима, они их усмеравају на развијање и усавршавање сопствених предиспозиција, пружају им корисне информације о личном стању моторичких способности. Континуирано праћење моторичких способности ученика у оквиру наставе физичког васпитања има задатак да сваки ученик добије информације о сопственом нивоу моторичких способности, да на основу добијених резултата добије одређене препоруке и савете како да побољша свој моторички потенцијал, као и да се у току тестирања ученици образују и разумеју значај физичке активности и моторичких способности за сопствено здравље.

physical performance and physical development of 7 and 10-year-old boys and girls. Journal of Human Sport and Exercise, 10(1), 259-268.

5. Čillík, I., Kollár, R., Kremnický, J., Pivovarniček, P., Kováčiková, M., Ďurják, O., Švachova, S. \& Murínová, A. (2014). Nivo opštih fizičkih performansi i fizičkog razvoja učenika uzrasta od 7 godina u Banskoj Bistrici (Banská Bystrica). Sportske nauke i zdravlje, 7(1).

6. Committee of Experts on sports Research. (1988). EUROFIT: European Test of Physical Fitness. Strasbourg, France: Council of Europe.

7. Cummins, A., Piek, J. P., \& Dyck, M. J. (2005). Motor coordination, empathy, and social behaviour in school-aged children. Developmental medicine and child neurology, 47(7), 437-442. 
8. Eccles, J. S., \& Harold, R. D. (1991). Gender differences in sport involvement: Applying the Eccles' expectancy-value model. Journal of applied sport psychology, 3(1), 7-35.

9. Esteban-Cornejo, I., Tejero-González, C. M., Martinez-Gomez, D., Del-Campo, J., González-Galo, A., Padilla-Moledo, C., Salis J., \& Veiga, O.(2014). Independent and combined influence of the components of physical fitness on academic performance in youth. The journal of pediatrics, 165(2), 306-312.

10. Gojković, G. (2010). Razlike motoričkih sposobnosti u odnosu na pol učenika. Sport Mont, 8 (2324), 423-428.

11. Griffiths, L. J., Cortina-Borja, M., Sera, F., Pouliou, T., Geraci, M., Rich, C., Cole, T., Law, K., Joshi, H.,Ness, A.,Dezateux, C., \& Jebb, S. A. (2013). How active are our children? Findings from the Millennium Cohort Study. BMJ open, 3(8), e002893

12. Jevtić, B., Radojević, J., Juhas, I., \& Ropret, R. (2011). Dečiji sport od prakse do akademske oblasti. Beograd: Fakultet sporta i fizičkog vaspitanja.

13. Krska, P., Sedlacek, J., Hubinak, A., Kostial, J., \& Teplicancova, M. (2017).Somatic parameters and general physical fitness level of school children (7-10 years) in town Ruzomberok in Slovakia. Gymnasium, 15(2).

14. Lazarević, P., Milosavljević, S., Lazarević, S., Marković, V., \& Savić, A. (2018). Different levels of motor abilities in boys and girls aged 10 and 9 . Facta Universitatis, Series: Physical Education and Sport, 16(1), 189-199.

15. Malina, M.R., \& Bouchard, C. (1991). Growth, maturation and physical activity. Human Kinetics Books: Champaign, 187-204.

16. Milanese, C., Bortolami, O., Bertucco, M., Verlato, G., \& Zancanaro, C. (2010). Anthropometry and motor fitness in children aged 6-12 years. Journal of Human Sport and Exercise, 5(2), 265-279.

17. Nettlefold, L., McKay, H. A., Warburton, D. E. R., McGuire, K. A., Bredin, S. S. D., \& Naylor, P. J. (2011). The challenge of low physical activity during the school day: at recess, lunch and in physical education. British Journal of Sports Medicine, 45(10), 813-819.

18. Nikolić, I., Mraković, S., \& Horvat, V. (2013). Standing long jump performance quality: Age and gender differences. Croatian Journal of Education, 15(1), 173-183.
19. Obradovic, J., Cvetkovic, M., \& Krneta, Z. (2008). Differences of motor abilities of 7-11 years old children according to geneder. Sport Mont, VI(1516-17), 527-533

20. Raudsepp, L., \& Pääsuke, M. (1995). Gender differences in fundamental movement patterns, motor performances, and strength measurements of prepubertal children. Pediatric Exercise Science, 7(3), 294-304.

21. Robinson, L. E., Stodden, D. F., Barnett, L. M., Lopes, V. P., Logan, S. W., Rodrigues, L. P., \& D’Hondt, E. (2015). Motor competence and its effect on positive developmental trajectories of health. Sports medicine, 45(9), 1273-1284.

22. Rowlands, A. V., Eston, R. G., \& Ingledew, D. K. (1999). Relationship between activity levels, aerobic fitness, and body fat in 8-to 10-yr-old children. Journal of Applied Physiology, 86(4), 1428-1435.

23. Simonsmorton, B. G., Taylor, W. C., Snider, S. A., Huang, I. W., \& Fulton, J. E. (1994). Observed levels of elementary and middle school children's physical activity during physical education classes. Preventive Medicine, 23(4), 437-441.

24. Sollerhed, A. C., Apitzsch, E., Råstam, L., \& Ejlertsson, G. (2007). Factors associated with young children's self-perceived physical competence and self-reported physical activity. Health Education Research, 23(1), 125-136.

25. Stupar, D. (2012). Differences in anthropometric characteristics and motor abilities between boys and girls age 7: Meta-analysis. TIMS. Acta, 6(2), 57-64.

26. Thomas, E., \& Palma, A. (2018). Physical Fitness Evaluation of School Children in Southern Italy: A Cross Sectional Evaluation. Journal of Functional Morphology and Kinesiology, 3(1), 14.

27. Tremblay, M. S., LeBlanc, A. G., Kho, M. E., Saunders, T. J., Larouche, R., Colley, R. C., Goldfield, G., \& Gorber, S. C. (2011). Systematic review of sedentary behaviour and health indicators in school-aged children and youth. International journal of behavioral nutrition and physical activity, 8(1), 98. 